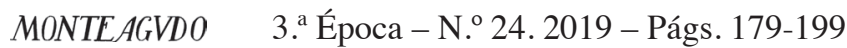

\title{
Moda Y LiTERATURA. Un CASO PARAdigmático: JUAN VALERA
}

\author{
Rocío RuIz CÁCERES \\ Universidad de Alicante
}

\section{RESUMEN:}

Los novelistas españoles del siglo XIX conceden gran importancia a la moda, a la forma de vestir como distinción social. El tema del «quiero y no puedo», entre otros, será un aspecto que dicte la conducta de numerosos personajes de ficción en la novela realista-naturalista. En el presente estudio se analiza la presencia de la moda en las novelas de Valera desde una doble óptica: la epistolar, correspondiente a sus cartas en las que se refleja la moda, y la narrativa, fundamentalmente sus novelas Pepita Jiménez, Doña Luz, Las ilusiones del doctor Faustino, Juanita la Larga y Genio y figura.

PALABRAS CLAVE:

Siglo XIX. Juan Valera. Literatura. Moda.
ABSTRACT:

Spanish novelists from the 19th Century give great importance to the fashion, the way of dressing as a social distinction. The issue of «I would like to, but I'm not able to», among others, it will be an aspect that dictate the behavior of many fictional characters in the realist-naturalist novel. This research analyses the presence of fashion in Valera's novels from a double perspective: the epistolary, corresponding to his letters in which fashion is reflected, and the narrative, mainly his novels Pepita Jiménez, Doña Luz, Las ilusiones del doctor Faustino, Juanita la Larga and Genio $y$ figura.

KEYWORDS:

19th Century. Juan Valera. Literature. Fashion.

La novela española, al igual que la europea, se nutre de forma insistente de los usos y costumbres que rigen en precisos contextos históricos, en determinadas corrientes estéticas, como en el caso de la novela realista-naturalista. Vestidos, objetos, adornos, muebles, adquieren en determinados momentos fuerza de ley, siendo, precisamente, el traje el protagonista esencial que refleja los gustos de la moda con total entidad, como en el caso de Juan Valera.

La moda está en las fiestas, en los saraos palaciegos, en las tertulias, en los círculos políticos y literarios tanto provincianos como cortesanos. Se manifiesta desde múltiples ópticas, desde la forma de andar, sentarse y comunicarse a través de 
determinadas variantes idiomáticas hasta en la misma prenda que forma parte de la vestimenta, de suerte que se introduce en el espacio literario, en el arte, e, incomprensiblemente, en la ciencia, en la filosofía. De esta influencia universal de la moda y no de la esencia verdadera de las cosas, está la naturaleza de dicho concepto, tal como se constata en la célebre frase del novelista y dramaturgo, coetáneo de Valera, Théophile Gautier, les femmes n'ont que le sentiment de la mode et non celui de la beauté (1918, XXXV: 1198). De igual forma, definiciones y concepciones sobre moda y forma de vestir emitidas por clásicos preceptistas imprescindibles en la literatura europea, como en el caso de Boileau, pueden considerarse válidas también para desentrañar el concepto moda al afirmar que l'histoire de la mode, c'est l’histoire de la folie (1918, XXXV: 1195), en clara alusión a la tiranía, al frenesí o sin razón de la moda, introducida hasta en los más tradicionales lugares, causando una verdadera renovación en las costumbres y obligando constantemente a reformar nuestras prendas de vestir, tanto las de la ropa interior como las del exterior, pues todas están sometidas a su imperio.

Desde la aparición de la primera novela realista, La Gaviota, de Fernán Caballero hasta las debidas a Valera, Alarcón, Pereda, Galdós, Pardo Bazán, Clarín, Coloma, Palacio Valdés, Blasco Ibáñez, se puede constatar tal apreciación ${ }^{1}$.

\footnotetext{
${ }^{1}$ Desde los orígenes mismos de la novela realista, como en el caso de La Gaviota, de Fernán Caballero, el vestido suele actuar como un tic caracterizador del comportamiento del personaje, de su forma de ser, de pensar o comportarse en sociedad. El doctor Stein en un primer momento es descrito como un hombre que «no indicaba elegancia y distinción» (2004: 72), todo lo contrario al personaje Pepe Vera, el famoso torero del que se enamora La Gaviota, la mujer del doctor Stein, detonante del adulterio y cuyo porte causa admiración, atracción: «su vestido era de raso color cereza, con hombreras y profusas guarniciones de plata. De la pequeña faltriquera de la chupa salían las puntas de dos pañuelos de holán. El chaleco de rico tisú de plata [...] completaban su elegante, rico y airoso vestido de majo» (2004:246). El casamiento de Stein y La Gaviota es un mosaico de trajes, de vestidos, «de tejidos de algodón traídos de Gibraltar, de contrabando. El dibujo de la vestimenta era el que dictaba la moda y le llamaba Arco Iris, por ser una reunión de los colores más opuestos y menos capaces de armonizar entre sí» (2004: 199).
}

Recordemos también las novelas de Galdós, su minuciosidad descriptiva sobre el vestido y la moda en el trasiego novelesco protagonizado por Rosalía, fundamentalmente en la novela La de Bringas. Tormento, Fortunata y Jacinta, Miau, entre otras novelas, existe un copioso material noticioso sobre la moda en el vestir y su adecuación a los rasgos personales de cada personaje. Los cuadros descriptivos de tipos debidos a Pereda o sus novelas como El buey suelto, por ejemplo, corroboran la esencia de la moda en parte de los tics caracterizadores de un determinado personaje, al igual que en el mundo de ficción de Pardo Bazán, como en El cisne de Vilamorta, La Tribuna, Los Pazos de Ulloa o la Madre Naturaleza. Recuérdese, por ejemplo, al protagonista de Los Pazos de Ulloa, don Pedro Moscoso, cuya vestimenta se adecua perfectamente a los círculos sociales frecuentados, fundamentalmente, en su visita a Santiago de Compostela a fin de contraer matrimonio. Otro tanto podemos apreciar en la novela de Clarín Su único hijo, en la forma de vestir de Bonifacio, trasnochado romántico, cuya vesti- 
Por ejemplo, en el caso de Valera, los grabados de Gibus publicados en el Petit Courrier o en Le Follet y los modelos de trajes pertenecientes a la célebre revista La Mode Artistic serán conocidos por la sociedad denominada del buen tono, la aristocrática, el círculo social al que pertenecía Valera, y era también conocida por el resto de novelistas anteriormente citados, a fin de reflejar en sus obras las múltiples variantes por las que discurre la moda en interrelación con la peripecia argumental de sus relatos. Elegantes trajes que coinciden, en no pocas ocasiones, por ejemplo, con los retratos de Guillermo Terri, llamado el príncipe de los elegantes, el figurín o modelo que pondría de moda en el último tercio del siglo XIX el sombrero Derby y el llamado gabán Ulster. Recuérdese también a Charles Frederick Worth, inglés afincado en París, considerado el padre de la alta costura, pionero en firmar sus creaciones y en ofrecer anualmente una colección que daría pingües beneficios económicos y una excelente posición social (Boucher, 1967; Bourdieu, 1999). No olvidemos que Valera ofrece un material noticioso de gran valor en referencia a la moda gracias a la correspondencia hoy publicada con su hermana Sofía, duquesa de Malakoff, residente en París y relacionada socialmente con toda la aristocracia europea. Una relación epistolar sincera y fluida iniciada en el año 1853 y concluida en 1889 (Sáenz de Tejada, 1974; Romero Tobar, 2002-2010) o las cartas escritas desde distintos países europeos y americanos relacionadas con la literatura y cultura, como las dirigidas a M. Menéndez Pelayo, Gumersindo Laverde y autores de su generación (Artigas, 1946; Brey de Rodríguez Moñino, 1984; DeCoster, 1956, 1981), colecciones epistolares reunidas recientemente por Romero Tobar (2002-2010) que incluyen tanto el material noticioso referido a la familia de Valera como a las de carácter íntimo, no exentas de notas eróticas, especialmente las escritas a Serafín Estébanez Calderón (Sáenz, 1971).

La primera noticia que tenemos de Valera relativa a la vestimenta aparece en época temprana, en la carta dirigida a su padre fechada el 21 de enero de 1847, en los preámbulos de sus inicios como diplomático y recién licenciado en Derecho: «En cuanto al uniforme, no lo haré de lo más sencillo [...] Yo creo que también necesito un frac azul con botones dorados diplomáticos para ir a bailes particulares, pues el que tengo no está nada elegante. De mis mesadas me he comprado dos chalecos de

menta se adapta a sus gustos literarios. Hombre que también sufre el autoritarismo de su mujer Emma en su forma de vestir, a cuyo dictado debe doblegarse a fin de no desentonar en los círculos sociales frecuentados por los Valcárcel. Recordemos también el casino de Vetusta, en La Regenta, sus tertulias, sus bailes, la disección social marcada por la moda en el vestir. El padre Coloma, en Pequeñeces, también nos ofrece un rico material de la forma de vestir de la aristocracia, desde la más acicalada dama palaciega hasta petimetres, lechuguinos o dandis en plenitud de su vida o en sus últimos años de existencia gracias al personaje Currita Albornoz, los lectores asistimos a una especia de lección en materia de costumbres, de actuaciones y forma de vestir de la aristocracia alfonsina. 
sociedad muy ricos, un camisolín de batista, una chorrera de encaje, unos pantalones, un gabán [...]» (2002, I: 35). Tres días más tarde, 24 de enero de 1847, en carta a Alonso Messía y de la Cerda, le advierte su interés por la moda femenina, pues comunica a dicho receptor de la carta que acaba de enviar a su hermana Ramona un sombrero «muy bonito, de terciopelo blanco springlé» (2002, I: 39). Es evidente que tanto su madre como sus hermanas son receptivas de cartas en donde Valera muestra y comenta asuntos referidos a la moda, fundamentalmente para comentar asuntos relacionados con la jet set, tal como gusta denominar Valera los saraos o fiestas en la que se entrecruza la burguesía con la aristocracia ${ }^{2}$.

Desde el año 1847, en el que Valera marcha a Nápoles como agregado de la Embajada, que desempeña el Duque de Rivas, hasta 1893 el escritor recorrerá las ciudades más importantes de Europa y América. Su presencia por numerosas legaciones y embajadas le permitirán conocer no sólo lo más trascendental del mundo cultural, de la política, sino también los comportamientos sociales del mundo de la burguesía, de la aristocracia, fundamentalmente. Lisboa, Río de Janeiro, Dresde, Rusia, Francfort, Washington, Bruselas, Viena serán enclaves fundamentales para conocer su epistolario, sus cartas dirigidas a un copioso número de corresponsales en el que se aprecia con nitidez los aspectos más esenciales de su vida profesional y familiar, desde sus experiencias como político, académico, crítico y escritor, hasta sus veleidades amorosas, penurias económicas o censuras a su matrimonio. Es evidente que la moda y la forma de vestir en general no ocupa en su epistolario el lugar relevante que tiene en sus novelas. De hecho, su ascendencia aristocrática y su experiencia como diplomático le permitirían conocer los círculos sociales más diversos de la época, proyectándose dichas vivencias y conocimientos sobre la moda en sus novelas. Una lectura del epistolario corroboraría estas apreciaciones. Así, desde Portugal, 28 de agosto de 1850, Valera le describe a su madre Dolores Alcalá-Galiano que las

\footnotetext{
${ }^{2}$ Sirva como botón de muestra la carta dirigida a su madre desde Madrid, 20 de febrero de 1850:

«Vamos ahora a hablar de aquel asunto secreto que anuncié a Vuestra Merced ayer. Creo, hará un mes cuando más, que vi en casa de [la condesa] de Montijo, y llamó mi atención por su gracia y elegancia, etc., una señorita, cuyo nombre ignoraba, pero a quien, sin embargo eché muchas miradas tiernas. Pregunté a Hinestrosa cómo se llamaba ella, y me dijo que la condesita de Tilly. Le rogué que me presentara y lo hizo. No he bailado con ella más que un rigodón, aunque la he hablado otras cuatro o cinco veces en los bailes [...]» (2002, I: 73)

Relaciones sociales que también encuentran feliz eco en las cartas dirigidas a su padre, como en la carta fechada desde Madrid el 3 de mayo de 1850:

«Esta afición mía a las faldas es terrible y si no fuera por lo caro que es Madrid y lo escaso que yo estoy de dinero para estar aquí en los círculos elegantes, andaría yo de reunión en reunión haciendo la corte a las damas, y buenas ganas se me han pasado de ponerme tierno y de visitar a la duquesita de A» (2002, I: 98)
} 
«mujeres se visten aquí de un modo bestial. Llevan capas como las de los hombres y un pañuelo blanco en la cabeza, tan puntiagudo y almidonado, que dan ganas de reír al verlas ${ }^{3} \gg$ (2002: I, 113).

Es bien sabido que Valera fue un bibliófilo en el sentido estricto de la palabra, pero ello no le impidió que reflexionara o describiera motivos relacionados con la moda desde múltiples ópticas, desde la condición social del personaje que ocupa una irrelevante ocupación, hasta la más bella meretriz de un lupanar distinguido, cantantes o damas de alta alcurnia poseedoras de numerosos títulos nobiliarios. Un recorrido por el rico y copioso epistolario de Valera desde los lugares más diversos de sus periplos diplomáticos constata tal apreciación. Así, desde Lisboa, 8 de enero de 1851 , en carta a su padre, elogia en reiteradas ocasiones a la célebre cantante de moda Stolz, famosa por sus vestidos y forma de accionar en el escenario. Más adelante en varias cartas a su amigo Serafín Estébanez Calderón, receptor de numerosas epístolas de corte erótico, le comentará los hechos de una «errante amazona» andaluza que ejerce la prostitución en los círculos aristocráticos, «que apenas cuenta 20 años de edad [...] dos ojos negros como endrinas, dulces y melancólicos [...] Y primor en el vestir» (2002, I: 156).

Prostituta que mantiene relaciones con lo más granado de la ciudad lisboeta, tal como le comenta en varias cartas dirigidas a Estébanez Calderón, fechada el 2 de julio de 1851 .

Durante su estancia en la Embajada Española de Brasil. Desde Río de Janeiro confiesa al citado Estébanez numerosas anécdotas personales, fundamentalmente amorosas como la protagonizada por una tal Mme Finet, una vendedora de guantes perfumes y objetos relacionados con la moda. El mismo Valera la describe con no poco gracejo: « En la calle principal de las tiendas, donde las hay lujosas y bien surtidas, no faltan ninfas del Sena, graciosas, y dadas a liviandades; pero esta escuela de amor, yo no la curso, pues en ella las mujeres son tomistas y los hombres escotistas» (2002, I: 183).

\footnotetext{
${ }^{3}$ El 25 de septiembre, desde Cintra, Valera comunica a su madre cuáles son sus diversiones preferidas: «mi mayor diversión ha sido recorrer con Figuera las platerías y las joyerías de las calles del Oro y de la Plata, entre las que no se puede negar que hay algunas magníficas, y en ellas objetos de mucho valor y elegancia, si bien esta es más rara» (2002, I: 119).

En dicha carta Valera describe pormenorizadamente también su habitación próxima a la legación española: una sala amplia con cortinajes al uso de la época, espejo, sillas de caoba, sillones, butacas «un velador, elegante también, y con la cubierta de jaspe, como la mesa del espejo. Una alcoba con una cama de caoba, mesa de tocador, cómoda, [...]» (2002, I: 119).
} 
Por regla general en todas las aventuras amorosas de Valera se destaca la elegancia y la limpieza de la mujer ${ }^{4}$.

En ocasiones una determinada prenda de vestir adquiere tonos caricaturescos para censurar o ridiculizar a una persona específica, como en el caso de la carta dirigida a Estébanez Calderón, 1 de septiembre de 1853, comentándole la suciedad de su jefe, el ministro plenipotenciario de España en Brasil, don José Delavat:

D. José se rasca cuando le pica, y como de continuo le pica, se rasca de continuo; y no dejándole los trabajos diplomáticos el tiempo suficiente para lavarse a menudo las manos, las trae siempre algo puercas, y con luto en las uñas. La pechera de la camisa, como él está gordinflón, y con la cabeza hundida entre los hombros, le hace un buen buche, y sobre él le cae el tabaco de polvo mezclado con los mocos y con la comida que le chorrea de los labios (2002, I: 251)

Desde las embajadas de Dresde y San Petersburgo Valera ofrece detalles sobre la forma de vestir desde una óptica distendida, confidencial y, en ocasiones, con socarronería, humor y no poca ironía. En Dresde, desde la Delegación de España, le comunica a su madre ciertas anécdotas ocurridas en los salones de la alta sociedad alemana, identificado el estereotipo del español con la figura del majo, con los tipos populares del Madrid castizo y de su Andalucía natal:

Días pasados estuve en un bailecito, y se empeñaron en que bailase el bolero. Yo me excusé con que no sabía [...]. Todos quisieran verme de majo y con un puñal, y que hubiese traído conmigo alguna hermana mía que fuese de mantilla y demás adminículos de maja; y aun disfrazado y todo de europeo, he notado con placer que muchas damas se quedan en éxtasis al contemplar mis hermosos ojos árabes, mis abundantes cabellos negros y mi fisonomía sarracena. (2002, I: 299)

\footnotetext{
${ }^{4}$ Tanto en su corpus epistolar como en sus novelas siempre insiste Valera en estos dos conceptos de vida: elegancia en el vestir y limpieza corporal. En sus devaneos amorosos y en época bien tempranas se puede constatar dicha apreciación, como, por ejemplo, en la carta dirigida a Estébanez Calderón (4 de agosto de 1853), una de las epístolas más extensas y graciosas de su epistolario desde el punto de vista erótico:

«Desde que llegué a Brasil, puso los ojos en mí una cotorrona sabrosa, ex-prima-donna, francesa de nación y casada hoy con el Alfio de Río - Janeiro, usurero riquísimo. Yo la había siempre desdeñado, pero D. José me aconsejó que cediese y me entregase. "Amigo, me decía, a falta de pan, buenas son tortas; harto sé que tal señora está ya algo madura, mas no está podrida [...]" Estas razones [...] me decidieron al fin, y ahora me alegro de veras. Mi prenda es blanca y rubia; elegantísima en el vestir, y más limpia que el oro; las carnes, frescas y apretadas; las piernas, como columnas de alabastro; y el brazo y la mano más lindos de la ciudad» (2002, I: 244).
} 
Con frecuencia Valera comunica a sus familiares y amigos el peculiar concepto que se tiene de España y de los españoles, especialmente desde el punto de vista de la vestimenta. Dicha sensación se entrecruza con otras percepciones sobre la forma de vivir en España, comparada con no poca frecuencia con obras literarias publicadas en nuestra literatura áurea. Así, en unas cartas dirigidas a Estébanez Calderón, 28 de febrero de 1855, leemos lo siguiente: «El vulgo nada sabe de nuestras cosas y finge, allá a su manera, una España medio salvaje, medio poética, donde pone galanes de Calderón, Gil Blases, bandoleros y D. Quijotes, vistiéndolos a todos de majos y haciéndoles bailar el bolero y la cachucha» (2002, I: 303).

En su epistolario también tenemos la percepción y descripción del propio Valera sobre los usos y costumbres de los alemanes, de su forma de vestir, «muy tiesos y siempre de corbata blanca», tal como le comunica a Estébanez Calderón (2002, I: 307). Apreciaciones que también aparecen en sus cartas escritas desde Rusia en San Petersburgo, en la Embajada Española cuyo ministro plenipotenciario era el duque de Rivas. Valera comunica a Leopoldo Augusto de Cueto la forma de vestir los criados de librea del emperador, el lujo extremo de su vestuario, de qué forma visten los rusos, el trasiego de sus calles, tiendas, coches, trineos que cruzan en todas direcciones. En una carta dirigida a dicho corresponsal se aprecia el detallismo realista del novelista en ciernes:

El hombre del pueblo lleva el caftán ceñido a la cintura con una faja de un color vivo botas de pieles o un género de calzado singular, que creo que se llama lapti, y en la cabeza una especie de acerico o almohadilla, tan desaforado a veces, que casi puede servir de almohada. Este es el traje de la gran Rusia, y también le usan los cocheros. Su expresión más sencilla en estos tiempos de frío entre la gente pobre es una zalea de carnero, amarrada al cuerpo con una soga, y todo ello ahumado y negro como una morcilla. El pellejo va por fuera y la lana por dentro [...]. (2002, I: 371)

La visión de la sociedad rusa sobre España apenas difiere de la llevada a cabo por los alemanes, tal como le comunica a su hermano en una carta fechada el 29 de diciembre de 1856 , pues nos consideran unos bárbaros y que «hay ladrones por todos los caminos, que nos vestimos todos de majo, que las señoras fuman y llevan el puñal en la liga» (2002, I: 358).

En los escarceos amorosos de Valera, desde el inicio mismo de la primera carta publicada, siempre, por regla general, el vestido asoma como un requisito sine qua non para un posible matrimonio, evidentemente ligado a la dote de la futura esposa al poco dinero que él mismo posee, pues como es bien sabido la falta de caudal siempre 
será una queja permanente en su vida, al igual que su matrimonio. Estas dos circunstancias serán sus dos jorobas, tal como él escribe, que tendrá que soportar a lo largo de su vida. A su hermano José Freuller, en una carta fechada desde Madrid el 1 de febrero de 1864, le dice que «el dinero es fundamental para casarse con una joven, pues tengo que vestirla primorosamente, enseñarle siquiera un poco de ortografía y a que no manotee ni haga guiñitos, y otras cosas que todas cuestan dinero, que yo no tengo, pues el que tengo, apenas alcanza para mí» (2003, II: 146).

Ya como ministro plenipotenciario en Francfort, Valera ofrecerá puntualmente noticias sobre la forma de vestir, aunque no de forma insistente, sólo ligeras pinceladas para ridiculizar a una determinada persona, como en el caso de la carta escrita a Gumersindo Laverde, el 13 de mayo de 1866. En otras epístolas habla de la carestía de los vestidos en España, en comparación con París. Así, en carta dirigida a su hermana Sofía le comunica que en España: «Para mantener a las dos señoras [su esposa y suegra], a mí, a los dos niños, que ya comen y a ocho o nueve criados, tendríamos que gastar en París tres veces lo que aquí gastamos. El teatro, la casa y casi todo lo demás, menos el vestido, es aquí más barato en el París» (2003, II: 454).

El epistolario de Valera ofrece múltiples perspectivas desde la mirada del propio autor, desde la política hasta la coreográfica, como en el caso del entronamiento de don Amadeo de Saboya en el que las aristócratas alfonsinas se vistieron de maja y con peineta, en señal de apoyo a los borbones ${ }^{5}$, hasta coreografías curiosas representadas en su Andalucía natal, en Doña Mencía ${ }^{6}$.

Se trata, en definitiva, de un mosaico de noticias sobre el vestido que a primera vista pueden pasar desapercibidas, aunque vistas desde el punto de vista de la ficción literaria, de sus novelas, son sumamente interesantes, pues actúan como bocetos literarios que se trasladan al mundo de ficción creado por Valera, tal como se constata en los perfiles, en la conducta y comportamientos de sus personajes, de las tertulias

\footnotetext{
${ }^{5}$ En una carta dirigida a su hermana Sofía, fechada en Madrid, 23 de marzo de 1871, le describe el comportamiento hostil de la aristocracia a la reina María Victoria de Saboya. El vestido ocupa en este contexto histórico un lugar prominente, fundamental:

«Para extremar esta manifestación han ido estos días a la Fuente Castellana algunas señoras, haciendo alarde de españolismo rancio, para probar su odio a los príncipes extranjeros. La condesa de Morny y la Acapulco han sido de las más conspicuas entre las españolísimas, yendo de máscara a la calle, vestidas de majas de 1808, con peineta de teja, mantilla [...]» (2002, II: 440).

${ }^{6}$ En carta dirigida a Menéndez Pelayo, desde Mencía, 25 de octubre de 1880, le comenta cómo combate sus horas de ocio: tertulias, partidas de cartas y otras diversiones, entre otras las fiestas coreográficas realizadas por Juanito el Bolero, bailarín de oficio en su juventud y convertido ahora en sastre. El vestuario propiedad del dicho Juanito lo describe Valera con primor: «Ocho vestidos o trajes completos de oficial inglés, para bailar el baile inglés; de aldeano francés Pompadour, para bailes finos franceses; de gallego, de torero andaluz [...]» (2004, IIII: 221).
} 
descritas en sus novelas, de los aristócratas arruinados o no que se comportan y visten de forma parecida al mundo real del autor.

En lo que respecta a la primera descripción sobre la forma de vestir realizada por Valera, cabe indicar que se encuentra en la colección costumbrista Las Mujeres Españolas, Portuguesas y Americanas publicada en la célebre imprenta de Miguel Guijarro en tres vols. (1872, 1873 y 1876). Se trata de una magna colección «limitada exclusivamente a la descripción de la mujer desde una perspectiva nueva, condicionada por las peculiares características del contexto geográfico en que se desarrolla su vida» (1993: 65-66). La colaboración de Valera se titula La mujer de Córdoba y solo ha sido tenida en cuenta por la crítica para señalar su relación con su novela Juanita la Larga, pues se nutre de aspectos y recuerdos plasmados en dicho cuadro de costumbres. Como afirma Montesinos, «Juanita la larga fue imaginada mucho antes que compuesta, y compuesta sobre seres y cosas que vivían en su memoria desde la niñez. De las dos hembras que la centran, Juana y Juanita, hizo expresa mención en aquel maravilloso ensayo sobre La Cordobesa» (1970:146).

Concomitancias entre el citado cuadro de costumbres que, sin embargo, nunca ha sido abordado desde el punto de vista de la moda, tal como era preceptivo en los fines de la colección, pues en el subtítulo de Las Mujeres Españolas, Portuguesas y Americanas se hace mención expresa a los trajes. Valera se ajusta, pues a este patrón y la describe con esmero y maestría:

Ella bordaba con primor, y no olvida jamás los mil pespuntes, calados, dobladillos y vainicas que en la miga le enseñaban, y que hizo y reunió en un rico dechado, que conserva como grato recuerdo. No queda camisa de hilo o de algodón que no marque, ni calceta cuyos puntos no encubra y junte, ni desgarrón que no zurza, ni rotura que no remiende. (1872, I: 286)

Valera evidencia las cualidades de la mujer cordobesa como costurera, como sastresa y modista, capaz de componer cualquier prenda del vestido. Incide también en las peculiaridades del vestido en consonancia con la condición social de los cordobeses. Si la mujer es rica vestirá con primor y limpieza. Si es pobre, vestirá los domingos y días festivos con las mejores galas guardadas en el fondo del arcón: mantón o pañolón de Manila, rica saya y mantilla para la mujer. El hombre no le anda a la zaga en limpieza y riqueza en la forma de vestir, pues viste una camisa «bordada con pájaros y flores, blanca como la nieve, un chaleco de terciopelo, una faja de seda encarnada o amarilla, un marsellés remendado, unos zahones con botoncillos de plata dobles y de muletilla, y unos botines prolijamente bordados de seda en el bien curtido becerro» (1872, I: 286). 
En dicho cuadro de costumbres hace también un elogio de la capa española, pieza imprescindible del cordobés. Presentarse sin ella en una ceremonia religiosa, tertulia o reunión familiar sería una falta de decoro, de respeto. Es necesario llevarla siempre, pues como toda vestidura talar da a la persona cierta amplitud, tono y prosopopeya. Sólo esta prenda es capaz de proporcionar a quien la lleva estos rasgos de distinción. No menos curiosa es la descripción del sombrero cordobés, su utilidad tanto en los momentos de calor como de frío, de sol o del aire, para sestear, inclinado hacia el morrillo o en el cogote, sosteniéndole en la mano para saludar a las personas que más respeto y consideración le merecen. Toda esta descripción de la forma de vestir se asemeja a las fisiologías francesas que a mediados del siglo XIX hicieron furor en Francia, y, años más tarde, en España, aunque Valera da al tipo descrito un rasgo y gracejo singular que suele brillar por su ausencia en dicho costumbrismo de tipos.

Es bien sabido que Valera publica su primera novela a los cincuenta años de edad, en plena madurez. Pepita Jiménez (1874) ha sido analizada desde múltiples ópticas, desde el proceso de composición y redacción, hasta sus posibles fuentes literarias. Su falso misticismo, recursos literarios, voces narrativas, vocación religiosa-amor humano, entre otros múltiples aspectos (Rubio, 2001), evidenciándose un absoluto silencio respecto a la presencia de ciertos tics de Valera referidos a la forma de vestir los personajes que, sin lugar a dudas, están en íntima conexión con sus comportamientos en el mundo de ficción. El cambio en el vestir o la forma del vestido discurre paralela a la esencia del personaje. Así, el carácter de don Gumersindo, el octogenario casado con la joven Pepita, viejo muy aseado y cuidadoso de su persona, utiliza un vestuario sencillo, aunque sus prendas «estaban algo raídas, pero sin una mancha y saltando de limpias, aunque de tiempo inmemorial se le conocía la misma capa, el mismo chaquetón y los mismos pantalones y chalecos» (1991: 85-86). Esta forma de vestir está en perfecta consonancia con la esencia del personaje, pues es ahorrador, no tiene lujos, ni vicios. Es un hombre limpio y poseedor de un importante caudal gracias a la conjunción de su temperamento y carácter que se materializan en unas simples pinceladas referidas al vestuario.

La conducta de Pepita Jiménez, su armonía, su carácter, se adecua perfectamente a su forma de vestir, de actuar, en su justo medio que se adapta a su naturaleza, a su personalidad: «No afecta vestir traje aldeano ni se viste tampoco según la moda de las ciudades; mezcla ambos estilos en su vestir, de modo que parece una señora de lugar; no se advierten en ellas, ni cosméticos ni afeites; pero la blancura de sus manos, las uñas tan bien cuidadas y acicaladas, y todo el aseo y pulcritud con que está vestida [...]» (1991: 101).

Se trata, evidentemente, de un vestido elaborado literariamente, de estudiada idealización, en consonancia con otros personajes femeninos correspondientes a sus 
novelas y que ya estaban presentes en su corpus poético. Lo importante es reseñar la adecuación del vestido ante los rasgos físicos de belleza que siente Valera. Un personaje que siempre mostrará decoro, hasta en los momentos más luctuosos, como a raíz de la muerte de su marido, que tras dejar el luto se muestra «más galana y vistosa con trajes ligeros y casi de verano, aunque siempre muy modesta» (1991: 158). La atracción que el joven seminarista experimenta al contemplar a Pepita Jiménez también está tejida mediante un escenario propicio en el que la forma de vestir actúa de un modo determinante. Cuando por primera vez Vargas está a solas con Pepita, después de quitarse la larga falda de montar, describirá en su carta dirigida al deán sus movimientos con primor, pues «caminaba con un vestido corto que no estorbaba la graciosa ligereza de sus movimientos Sobre la cabeza llevaba un sombrerillo andaluz, colocado con gracia. En la mano el látigo, que se me antojó como varita de virtudes, con que pudiera hechizarme aquella maga» (1991: 146).

Pepita Jiménez luce todos sus encantos a fin de atraer a don Luis, cuidando pormenorizadamente los atuendos, su vestimenta, para conseguir enamorar al joven. El narrador es bien explícito en su propósito, pues comunica a los lectores que «Pepita empleó más de una hora en estas faenas de tocador, que habían de sentirse sólo por los efectos. Después se dio el postrer retoque y vistazo al espejo con satisfacción mal disimulada» (1991: 245). Como es bien sabido la cita amorosa tendrá un final feliz. Don Luis colgará los hábitos y se comportará de forma bien distinta a partir de este instante, enfrentándose al conde de Genazahar y venciéndoles en el duelo. Valera enlaza este duelo en un contexto costumbrista de ilustre tradición literaria, el casino, lugar frecuentado «por la flor y nata de los elegantes, dandies y cocodes», de cuyo grupo destacaría el conde de Genazahar, un buen mozo de treinta y tres años, ducho en lides y en desafíos amoroso, que por despecho amorosos se burlará de Pepita y provocará el consabido duelo.

Por regla general Valera describe a sus heroínas de ficción sin alardes de lujo, a pesar de conocer a la perfección los gustos y modas del siglo XIX. Son mujeres elegantes, amantes de la vestimenta tradicional, como es el caso de doña Luz, de porte «grave, silenciosa, vestida toda de negro, con basquiña y mantilla» (1990: 58). La novela Doña Luz introduce de forma aislada personajes o tipos representativos del dandismo, como en el caso de don Jaime de Pimentel, descrito como un dandy, «flor y nata de los elegantes de Madrid» (1990: 153) y descrito por los lugareños con el apodo de currutaco. Un hombre infame que se casará con doña Luz gracias al engaño y movido sólo por intereses materiales. 
Del resto de su producción novelesca cabe destacar algunos destellos sobre la moda, especialmente a través de las heroínas de ficción, como en el caso de Las ilusiones del doctor Faustino, a través de las mujeres Constancia, Rosita y María, símbolos del orgullo, el amor sensual y el afecto espiritualizado, respectivamente. Tres mujeres que discurren en el mundo de ficción por los cauces del erotismo, de la pasión amorosa ${ }^{7}$.

Sirva de ejemplo la forma de vestir de Rosita, en las visitas que el doctor Faustino lleva a cabo en su casa, o durante la enfermedad de dicho personaje después del lance amoroso con su prima Constancia y duelo con su esposo, el marqués de Guadalbarbo. Una sirvienta antigua de Constancia será, precisamente, quien nos ilustre sobre las modas en sus visitas a don Faustino, pues a fin de evitar su señora un posible escándalo con su presencia en la habitación donde está instalado, será la criada la portadora de sus mensajes ${ }^{8}$. Valera se sirve de este personaje para ilustrarnos sobre la moda, tanto en perfumes de la época famosos, como en la vestimenta:

En torno suyo se difundía una fragancia exquisita a oppopomax, que era entonces el perfume más chic y de las más alta nouveauté que destilaba por sus alambiques The Grown Perfumery, de Londres. Su traje, su sombrerillo, sus movimientos y sus modales todo era o aspiraba a ser distinguido. Se diría que el último figurín de La Moda Elegante Ilustrada se había animado por arte mágica y entraba allí de visita. (1968, II: 347)

Las referencias a la moda son constantes en la obra de Valera, sin embargo existe una novela que aglutina todos sus conocimientos sobre la vestimenta, el traje, los gustos y tendencias en el vestir: Juanita la Larga. Como es bien sabido la novela ha sido definida o analizada desde diversas ópticas, en ocasiones como el último

\footnotetext{
${ }^{7}$ En Las ilusiones del doctor Faustino el vestido es también utilizado para explicar el desajuste del siglo XIX, tal como se constata en la introducción de la novela:

«Va a Madrid un joven bien plantado, chistoso, ameno, que se viste con el mejor sastre y se pasea en la Castellana. No se enamoran de él las duquesas ni las marquesas; las ricas herederas le dan calabazas, y solo se muestra propicia, si acaso, la hija del ama de la casa de huéspedes donde vive». (1968, II: 206)

${ }^{8}$ La criada antigua se presenta ante don Faustino convertida en propietaria de una casa de modas. Su historia parece un cuento encartado en la peripecia argumental de la novela:

«Yo soy la antigua doncella de la señora marquesa de Guadalbarbo. ¿No se acuerda usted de Manolilla?- Ah, si...- He tomado el nombre de Etelvina, porque el de Manolilla era vulgar y prosaico. Serví muchos años a la señora marquesa; me casé con Monsieur Mercier, el jefe de su cocina, eminente químico. Luego enviudé, y con los ahorros míos y del difunto, que en paz descanse, he puesto tienda de modas Ya se conoce que el señor Faustino es un filósofo que no se preocupa de estos negocios de cocodetería. Si no ¿cómo había de ignorar quién es la famosa Etelvina Mercier o la Etelvina a secas? En los círculos aristocráticos no hay persona más conocida que yo en el día de hoy. Hago furor. Estoy muy recherchée.» (1968, II: 347)
} 
idilio clásico de la literatura española (Montesinos: 149); como caricatura rural del amor que Herrera profesó por la condesa de Gelves (Entrambasaguas, 1972: 253); en otras, desde las interrelaciones del religiosos con las heroínas de ficción (Pérez Gutiérrez, 1975: 523) o en su conexión con el costumbrismo andaluz (DeCoster, 1961: 200-216; Bravo Villasante, 1974) y desde el punto de vista de las técnicas narrativas (Gullón, 1976), entre otros múltiples aspectos. Sin embargo, desde el punto de vista de la moda, del traje en interconexión con la peripecia argumental, las referencias suelen ser escasas, aunque se han utilizado para fijar la fecha del desarrollo de la acción novelesca gracias a las publicaciones periódicas citadas por Valera en Juanita la Larga (Rubio, 1986). Como es bien sabido, la protagonista que da título a dicha novela, Doña Juana, está descrita por Valera como una de las mejores modistas de la localidad, por lo que no era de extrañar que ella y su hija pudiesen vestir con los trajes más bonitos del lugar, aunque la calidad de los tejidos no fuesen los mejores, ya que ahí era dónde se evidenciaba el poder económico: «Casi siempre tenía una o dos oficialas que cosían para ella, y ella cortaba vestidos, con tanto arte y primor, como Worth y la Doncet en la capital de Francia» (1986: 84).

Resulta llamativo cómo se compara a doña Juana con el gran modisto Charles Frederick Worth, considerado el primer diseñador de la alta costura francesa, como hizo también Galdós en La de Bringas. Nadie en su época supo ver la moda como él, pues elevó la indumentaria a la categoría de arte. Fue él quien vistió a las mujeres consideradas más bellas y elegantes de la época. Y lo mismo se dice de las mujeres vestidas por Juana, lo que supondría todo un honor para ella, ya que la consideraban la mejor en el arte de la confección. «Las señoras y señoritas más pudientes y aficionadas al lujo acudían, pues, a Juana para sus trajes de empeño, cuando había que lucirlos, ya en una boda, ya en una feria o ya en el baile que solía darse en las Casas Consistoriales el día del Santo Patrono» (1986: 84).

Don Paco, el viudo enamorado de la joven Juanita que la deseaba cada día más, no veía el modo de acercarse a ella sin asustarla, debido a su gran diferencia de edad. De nuevo el tema de la moda será ese nexo de unión entre ambos personajes. Conexión sin la cual sería casi imposible poder acercar a dos personajes tan antagónicos:

Así discurriendo, pasó don Paco revista a su ropa blanca. Vio que sólo tenía media docena de camisas bastante estropeadas y con muchos zurcidos. Y como esto era muy poco para él, persona de extremado aseo, que ¡cosa rara en un pequeño lugar! Se ponía ropa limpia tres veces a la semana, decidió que estaba justificadísimo el mandar que le hicieran media docena de camisas nuevas, que le hacían muchísima falta. ¿Y quién había de hacerlas mejor que Juanita, que era la costurera más hábil de Villalegre? ¿Y quién había de cortarlas mejor que su madre, la cual, lo mismo que con el mango de la sartén en la izquierda y la 
paleta en la diestra, era una mujer inspirada con las tijeras en la mano y con cualquiera tela extendida sobre la mesa y marcada ya artísticamente con lápiz o con jaboncillo de sastre?.(1986: 100-102)

Tan complacido estaba el hombre por el trabajo bien hecho que quiso regalar una pieza de tela a la joven hija de la costurera para que la luciese como debía:

Tengo yo una pieza de tela de seda, flexible y rica, por el estilo de la de estos mantones que llaman de espumilla o de Manila. Carece de bordados y es de color verde oscuro. Me la envió meses ha de regalo mi sobrino Jacintico, que está en Filipinas empleado en Hacienda. Tiempo hay todavía de hacer con esta tela un precioso vestido de mujer [...] La tela es pintiparada para hacer el traje, y si ustedes quieren darse prisa, aún tienen tiempo de sobra [...] Ambas mujeres admiraron aquella hermosura; la calificaron de divina [...] En suma, no pudieron resistir y aceptaron el obsequio [...] La tela es encantadora [...]. (1986: 119-120)

En agradecimiento a tal presente, decidieron ambas agasajarle con una levita nueva que harían igual que el último figurín de una de las revistas de moda más importantes del momento: «Sin chistar, con mucho sigilo, vamos tú y yo a hacerle una levita nueva, según el último figurín de La Moda Elegante e Ilustrada que recibiste de Madrid el otro día» (1986: 120-121). La alusión a tal periódico en el que la moda era el tema principal, nos hace partícipes de cómo Valera conocía las publicaciones de moda y cómo influían sobre la sociedad de la época, en la que las apariencias venían dadas a través de la imagen personal. De hecho, nos explica de nuevo cómo vestían el día grande de la feria de Villalegre, que se celebraba el día 4 de agosto 9 .

Contemplamos, pues, cómo la vestimenta influía de forma determinante en la sociedad, de ahí que las descripciones tan detalladas que nos ofrece el autor posibilita

${ }^{9}$ El texto literario describe con precisión los detalles de la vestimenta: «Los hombres, bien afeitados [...] Los señores más importantes y ricos, cuantos recibían el tratamiento de don, estaban de levita y castora, y hasta con el frac dos o tres, el escribano entre ellos. Los jornaleros, de camisa limpia y con sus mejores ropas, si eran jóvenes, iban en cuerpo, pero con chivata o larga vara de membrillo, oliva y fresno, y si eran ya mayores de edad, con capa, para el conveniente decoro, por ser allí la capa el traje de etiqueta [...] Las mujeres [...] ninguna iba con la cabeza descubierta. Todas, si no tenían mantilla, llevaban mantones de lana ligera, o bien pañuelos que denominaban allí seáticos, o sea de percal lustrosísimo, que imita la seda. Las damas pudientes, ya provectas, vestían trajes negros u oscuros de tafetán, de sarga malagueña o de alepín y de cúbica; y las señoritas, sus hijas, iban con trajes de muselina o de otras telas aéreas y vaporosas, pero ninguna sin mantilla, ora de tul bordado, ora de blonda catalana o manchega. Sobre la pulidez y el aseo del peinado, y como matorral al pie de enhiesta torre, relucían, junto a las peinetas de carey, las moñas de jazmines, la albahaca y otras hierbas de olor, y las rosas y los claveles rojos, amarillos, blancos y disciplinados [...]. El secretario don Paco estaba al lado del alcalde, con su levita nueva, elegantísimo [...]». (1986: 128-132) 
no sólo que nuestra imaginación vuele rápidamente hasta la época en la que tuvieron lugar los hechos, sino que también veamos cómo iban vestidos los personajes, sus características físicas y sus caracteres, incluso cómo sentían celos los unos hacia los otros por la manera de vestir. En un tiempo en el que la abundancia no era lo habitual, las gentes se preocupaban simplemente por su aspecto físico, por aparentar una posición superior. Aspectos como la bondad, la humildad, la sencillez no eran valorados, ni siquiera eran tenidos en cuenta a la hora de considerar a una persona, pues lo verdaderamente importante era su porte, la vestimenta. Como sucedió el día en el que las dos Juanas aparecieron en la iglesia cuando ya empezaba la misa. Los hombres murmuraban de admiración al contemplar su belleza, su elegancia, mientras las mujeres renegaban con envidia y resentimiento: «Detrás venía la hija; hecha un sol, con su lindo vestido de seda chinesca, su mantilla de madroños, su alta peineta de concha y un montón de claveles junto a la peineta» (1986: 135). Es entonces cuando el padre Anselmo, muy severo en su moral, muy religioso, y muy amigo del orden, de la disciplina y del respeto a la jerarquía social, inicia su acometida contra Juanita la Larga, al censurar el corte y la riqueza del vestido, impropio de su cuna y su linaje ${ }^{10}$. En este punto, las críticas no sólo surgen del párroco, sino también de la hija de don Paco, doña Inés, que parece ser la única con categoría suficiente para poder lucir mejor que todas las mujeres de Villalegre. Ella también reprende a la joven, que la tilda de desvergonzada:

[...] la desvergonzada mozuela se ha encajado en la iglesia, no vestida humildemente, según su clase, sino con el lujo escandaloso de las mujeres cortesanas que bullen en las grandes ciudades y que son la perdición de los hombres. ¿De dónde ha salido el traje que llevaba puesto? Aquí nadie lo ignora. Era regalo de usted.

-No he de negar yo que era regalo mío. Ella le aceptó por no desairarme, pero como me ha dado en cambio prenda de más valor, nadie puede decir que se viste a mi costa. Juanita se viste bien o mal con lo que gana trabajando de un modo honrado y lícito, y no estando

\footnotetext{
${ }^{10}$ Las palabras del padre Anselmo son asaz duras: «Declamó mucho el padre contra el feroz empeño que muestran hoy tantas personas por salir de su clase y elevarse sin mérito suficiente [...] y las mozuelas desvergonzadas, damas y grandes señoras. Contra todos estos abusos disertó con vehemencia o más bien lanzó centellas y rayos discurriendo más por extenso sobre el lujo femenino y encareciendo los males que de él proceden [...] Además de escandalizar con aquel lujo y de provocar a los hombres hasta en los lugares sagrados, turbando el sosiego de los espíritus e impidiendo su elevación, se gasta para sustentar dicho lujo más de lo que honradamente se gana; se aceptan regalos de los pretendientes y se les sonsaca el dinero. Dejándose ir, pues, por pendiente tan resbaladiza, las muchachas pobres, que se ponen muy majas, dan con facilidad en busconas [...] En suma, el padre Anselmo estuvo muy bien aquel día: censuró el vicio sin censura al vicioso, y no designó ni aludió a nadie. De esto se encargó la maliciosa envidia de las mujeres, excitada con disimulo por doña Inés». (1986: 139-140)
} 
vigentes en el día la pragmática contra la seda ni ningunas otras leyes suntuarias, no sólo de seda sino de oro y de perlas puede vestirse Juanita si tiene dinero para comprar el vestido y si se le antoja engalanarse con él [...] ¿Cómo defender el escándalo, la campanada que ha dado esa chica, transformada de repente en princesa, como en los cuentos de hadas? [...] emperegilándose con ricos trajes y mantillas de madroños como dicen que en Madrid van a los toros las damas de alto copete y las majas de rumbo. (1986: 152-153)

Advertimos, pues, que a las altas esferas sociales nunca les ha gustado que las inferiores que vistan como ellas, ni las igualen en belleza. De hecho, la moda surgió como esa forma de diferenciación social, donde las clases más altas podían permitirse los tejidos más lujosos y bellos que existían, mientras que para las clases populares resultaban inaccesibles, imposibles de obtener, aunque sí deseables.

En la obra de Valera la propia Juanita se da cuenta de que lo que ha provocado con su atuendo no debería haberlo hecho, ya que no es adecuado para su posición:

Dios me libre también de recaer en la mala tentación de presumir de princesa. [...] nada tampoco de ponerme magnífico vestido de seda mientras no gane posición, autoridad y título duradero, suficiente y legítimo, para tamaña audacia. Ahora me conviene seguir por un justo término medio: salir poco de casa, coser y bordar mucho, e ir con frecuencia a la iglesia, a misa y a mis devociones, muy humilde, con vestidito de percal y cobijada con un mantón modesto y oscuro. (1986: 165)

Aunque no renuncia a vestir como dama joven y rica, pues, en su ropa interior no escatimará el dinero, en su apariencia exterior seguirá vistiendo como se espera que lo haga una joven como ella: «Quiero ser cuidadosa y muy regalada en mi ropa blanca interior. En los ratos de ocio, con mis ahorrillos y cuando no cosa para la calle, he de hacerme camisas finas y enaguas bordadas como no las use mejores una archiduquesa de Austria. Tapado todo ello con el mezquino traje exterior» (1986: 166).

Juanita siguió los pasos de su madre como costurera, convirtiéndose en la mejor del lugar. La moda le sirve a Juanita como medio para el ascenso social que tanto anhela, no por la proeza de ser admirada y envidiada por otras mujeres, sino por el hecho de no quedar estancada en una clase social inferior. La costura la convierte en una gran creadora de piezas únicas a la que todos acuden para ir bien vestidos: 
Llegó en esto el invierno, y doña Inés quiso vestir a todos sus niños con buena ropa de abrigo. Juanita alcanzaba ya alta reputación de costurera. Todo lo que pudiesen hacer Serafina y otras del lugar era una chapucería cursi, si se comparaba con las confecciones de nuestra heroína, que estaba al corriente de las últimas modas de París, que recibía los figurines, y que, ajustándose a ellos, sin encadenar servilmente su fantasía a una imitación minuciosa, ideaba, trazaba, cortaba y hacía trajes para las mujeres dignos de figurar en los salones de la corte y de ser descritos por Montecristo o por Asmodeo, y para los niños y niñas, no inferiores por su gracia y por su chic a aquellos con los que la prole de un milord opulento o de un banquero inglés se engalana [...] En fin, doña Inés se dio a pensar y a repensar en lo muy preciosos que estarían sus niños con los trajes que Juanita les hiciese; venció la repugnancia que sentía contra ella, la llamó a su casa y le encomendó trajes para todos, según la edad y el sexo de cada uno [...] Los niños, con los trajes hechos por Juanita, salieron tan bien vestidos el primero de Noviembre, día de todos los Santos, que daba gloria verlos, y la gente los admiraba y los seguía en la calle. (1986: 173-175)

Esa fama que Juanita adquirió debido a su incesante e impecable labor la eleva a un nivel en el que ella se encuentra feliz y reconfortada, pues constata que su trabajo es valorado positivamente, que todos quieren vestir con prendas hechas por ella. La heroína, descrita por Valera como una joven fuerte para hacer frente a todos, trae a sus pensamientos el tema del amor con don Paco y se da cuenta de que la amistad que creía sentir por él no es tal, sino amor, verdadero amor: «Así y no muy poco a poco sino de prisa, reconoció Juanita que el aprecio y la amistad que siempre le había inspirado don Paco se convertían en amor, y que el amor aumentaba a pesar de tener más de medio siglo su objeto» (1986: 192). Y sintiéndose fuerte y valiente se lo confiesa a su madre: «le amo: perdidamente le amo» (1986: 202). Tras este secreto descubierto, decide contar a todos sus sentimientos por su amado, para, finalmente, iniciar los preparativos y comunicar el narrador a los lectores datos sobre él:

[...] sacó del armario el famoso vestido verde de seda, regalo de don Paco.

Ella había tenido cuidado de refrescarle y de modificarle, dejándole a la moda del día. Con tela que tenía de sobra el corte y que ella había guardado, se había hecho un nuevo corpiño de medio escote, a propósito para recepciones y tertulias. Se puso este vestido, se miró al espejo y quedó muy satisfecha encontrándose bien.

Al volver Rafaela y al ver a Juanita vestida de gala, tuvo nuevo motivo de admiración. (1986: 286)

Resulta curioso que el vestido que provocó la burla y a ser el centro de las chanzas del pueblo posibilita la admiración, sintiéndose querida y respetada por todos, 
consiguiendo así con creces su principal deseo: la boda con don Paco. Hecho que provocaría la alegría de todos, pues hasta don Anselmo, tan duro con ella en el sermón del día de Santo Domingo por culpa de sus palabras sobre su forma de vestir y aparentar una falsa posición social, cambiaría de actitud, regalando a la joven una pieza de tela para hacerse un buen traje: «El padre Anselmo, viendo que don Andrés y los señores de Roldán hacían regalos muy lucidos, no quiso ser menos hasta donde sus recursos lo consintiesen. Y con el fin de que su regalo tuviese el significado de retractación y palinodia, prometió hacer venir de Madrid un lujoso corte para un vestido de seda» (1986: 288).

$\mathrm{Al}$ pertenecer en este preciso instante a una categoría social más elevada a la suya, le estaba permitido ya lucir los tejidos que deseara, los más bonitos y lujosos. Ya no fingiría pertenecer a otra clase social a través de su vestimenta, sino que la indumentaria denotaría su pertenencia a un nivel social superior. El tema del «quiero y no puedo» desaparece en el mismo instante en el que Juanita se casa con don Paco, diluyéndose la diferencia social y así poder engalanarse con vestidos propios de su nueva clase social.

Cabe señalar, finalmente, las referencias a la moda correspondientes a la última novela publicada en su época madura, la conocida por la crítica con el nombre de novelas del segundo ciclo. Genio y figura, pues Morsamor, la última del ciclo, escapa de las directrices seguidas en el presente artículo, al contrario de la ya citada Genio y figura, novela que relata las aventuras galantes de Rafaela, una prostituta en su adolescencia que accede al gran mundo social, a la aristocracia, con singular inteligencia y desenfado. Valera concede al traje, al vestido una importancia trascendental, en consonancia con el cambio de personalidad e inteligencia del personaje literario. Gracias al vestido, Rafaela consigue pulir a su marido, introducirle en los lugares más refinados y conseguir así acrecentar sus ganancias económicas mediante sustanciosos contratos y proyectos empresariales:

Rafaela era insaciable en su anhelo de perfección, y, deseosa de que don Joaquín estuviese no sólo aseado, sino chic, y como ella le decía hablando en portugués, muito tafulo o casquillo [lechuguino], hizo que le tomasen las medidas y escribió a París y Londres encargándole ropa, que no tardaron en enviarle. Como por los pantalones era por donde más había claudicado, mandó Rafaela que se los hiciese en adelante un famoso especialista, culottier, que por entonces había en París, rue de la Paix, llamado Spiegelhalter. De los fracs y levitas se encargaron en competencia Cheuvreuil, en París, y Poole, en Londres. Las camisas, bien cortadas, sin bordados, ni primores de mal gusto, pero también sin buches, vinieron de las mejores casas parisienses [...]. (1986: 78) 
Extensa cita que sólo es una pequeña parte de la lección magistral que Valera escribe en su novela sobre el traje, pues a continuación cita famosas casas de modas de París, como las de Charvet y Tremlett. No prescinde tampoco Valera del calzado pues comenta y detalla con precisión no sólo cuál es el modelo más deseado, sino también quiénes son los mejores modelistas de la actualidad, como el célebre Hellstern o Costa. Gracias al vestido, don Joaquín se transmuta, se convierte en un hombre nuevo, era, tal como cuenta el narrador una «oruga, asquerosa y fea durante el período de nutrición y crecimiento, que por milagroso misterio de Amor, y para que se cumplan sus altos fines, transforma la mencionada deidad en brillante y pintada mariposa» (1986:79).

El vestido transforma a los personajes, cambia la identidad de los mismos y los traslada a esferas sociales superiores. Las referencias a Francia son numerosas y siempre como referente de la moda, tal como se constata en el capítulo XXIV, en que todos acuden a París como si fuera una peregrinación sagrada con tal de vestir como la high life, pues las mujeres «van a comprarse dijes, afeites y mudas, a vestirse con Worth [...]» (1986: 171). Salones, fiestas, paseos serán las principales galerías o escaparates del vestido, del traje, los referentes más significativos. Un mundo social en el que no faltan los dandys, los gomosos, los lechuguinos que visten y viven pendientes del último patrón de la moda de París. Valera, en definitiva, teje una historia en Genio y figura ligada también a la moda, como un claro rasgo distintivo para discernir sobre las cualidades humanas de los personajes en los últimos años de su vida. Instantes antes de su suicidio, Rafaela, la protagonista, alude a la vejez, a las enfermedades que destruyen no sólo al ser humano, sino también su cuerpo. El vestido como distinción forma debe ir ensamblado, unido, al espíritu, a los sentimientos, a todo aquello que se identifique con la riqueza espiritual de las personas. El vestido por sí sólo no es nada, sino una imagen vacía, de ahí que sea necesario la absoluta conjunción de ambos -vestido y personalidad- para distinguir a la mujer en la vejez:

Su aristocrática distinción era formal y somera; no procedía de lo íntimo y de lo esencial, sino de la forma exterior y de los atavíos que la engalanaban. Para mujeres tales, la vejez no llega sola sino que viene acompañada de la vileza, de la ruindad en que nacieron y en que vivieron hasta envolverse en el alucinador artificio de que al fin la vejez las desnuda (1986: 253)

Las novelas de Valera pueden interpretarse desde múltiples ópticas, desde su tendenciosidad no intencionada hasta las variadas formas de construir su mundo de ficción. La moda no es, evidentemente, uno de los ejes fundamentales y determinantes en su quehacer novelesco, pero sí un sustento, un complemento literario que 
acompaña o se adhiere a la personalidad de los personajes, a sus formas de actuar, de percibir la vida. El mundo de la moda proporciona a Valera un material noticioso auténtico, veraz, en correlación siempre con su propia vida, condicionada por su profesión como diplomático y perfecto conocedor de la sociedad de buen tono, tal como se conceptuaba a la burguesía y a la aristocracia en la época que le correspondió vivir a Valera.

\section{Bibliografía}

Artigas Fernando, Miguel y Sáinz Rodríguez, Pedro (eds.), Epistolario de Valera y Menéndez Pelayo (1877-1905), Madrid, Espasa-Calpe, 1946.

Ayala, $\mathrm{M}^{\mathrm{a}}$ de los Ángeles, Las colecciones costumbristas (1870-1885), Alicante, Universidad de Alicante, Secretariado de Publicaciones, 1992.

Boileau, Nicole, «La moda» en Enciclopedia Universal Ilustrada, Madrid, Espasa-Calpe, 1918, Tomo XXV, pág. 1195.

Boucher, François, Historia del traje en Occidente desde la antigüedad hasta nuestros días, Barcelona, Montaner y Simón, 1967.

Bourdieu, Pierre, La distinción: Criterio de bases sociales del gusto, Madrid, Taurus, 1999.

Bravo Villasante, Carmen, Biografía de don Juan Valera, Madrid, Editorial Magisterio Español, 1974.

DeCoster, Cyrus C. (ed.), Correspondencia de don Juan Valera (1895-1905), Madrid, Castalia, 1956.

- - - - , «Valera and Andalusia», Hispanic Review, XXIX, 1961, págs. 200216.

- - - - - Juan Valera, Boston, Twayne, 1975.

Gautier, Théophile, «La moda», Enciclopedia Universal Ilustrad, Madrid, Espasa-Calpe, 1918, Tomo XXXV, pág. 1198.

Montesinos, José F., Valera o la ficción libre, Madrid, Castalia, 1970.

Pérez Gutiérrez, Francisco, El problema religioso en la generación de 1868. Valera, Alarcón, Pereda, Pérez Galdós, Clarín, Pardo Bazán, Madrid, Taurus, 1975.

Romero Tobar, Leonardo (ed.), Juan Valera. Correspondencia, Madrid, «Nueva Biblioteca de Erudición y Crítica», Castalia, 2002-2008, 7 vols.

Rubio Cremades, Enrique (ed.), Juan Valera, Madrid, Taurus, Serie El escritor y la crítica, 1990.

- - - - , Panorama crítico de la novela realista-naturalista española, Madrid, Castalia, 2001. 
Sáenz de Tejada Benvenuti, Carlos (ed.), Juan Valera. Cartas íntimas, Madrid, Taurus, 1974.

Valera, Juan, «La mujer de Córdoba», en Las Mujeres Españolas, Portuguesas y Americanas. Tales como son en el hogar doméstico, en los campos, en las ciudades, en los templos, en los espectáculos, en el taller y en los salones. Descripción y pintura del carácter, costumbres, trajes, usos, religiosidad, belleza, defectos, preocupaciones y excelencias de la mujer de cada una de las provincias de España, Portugal y América e ilustrada por los más notables artistas españoles y portugueses, Madrid- La Habana- Buenos Aires, Imprenta y Librería de D. Miguel Guijarro, editor, 3 vols, I, 1872; II, 1873 y III, 1876.

- - - - , Obras Completas, Madrid, Aguilar, 1968, 3 vols.

- - - - , Juanita la Larga, en Las mejores novelas contemporáneas, Edición de Joaquín Entrambasaguas, Barcelona, Planeta, 1972, I, págs. 437-529.

- - - - , Doña Luz, Edición de Enrique Rubio Cremades, Madrid, EspasaCalpe, 1990.

_- - - - , Pepita Jiménez, Edición de Enrique Rubio Cremades, Madrid, Clásicos Taurus, 1991.

- - - - , Genio y figura, Edición de Cyrus DeCoster, Madrid, Cátedra, 1986. 